\title{
Effect of Axial Distribution of Gadolinium Burnable Poison in Advanced Pressurized Water Reactor Assembly
}

- Hend M. Saad

Nuclear Safety Engineering Department, Nuclear and Radiological Regulatory Authority, Nasr City, Cairo, Egypt ORCID: https://orcid.org/0000-0002-9558-6547

- Riham Refeat

Nuclear Safety Engineering Department, Nuclear and Radiological Regulatory Authority, Nasr City, Cairo, Egypt

ORCID: https://orcid.org/0000-0002-4940-5418

- Moustafa Aziz

Nuclear Safety Engineering Department, Nuclear and Radiological Regulatory Authority, Nasr City, Cairo, Egypt

ORCID: https://orcid.org/0000-0001-7736-2606

- H. Mansour Physics Department, Faculty of Science, Cairo University, Giza, Egypt ORCID: https://orcid.org/0000-0001-5685-955X

The radial and axial power distribution in power reactors are determined mainly by the patterns of the fuel assembly and the burnable absorber at the beginning of cycle. In Advanced Pressurized Water Reactor (APWR), gadolinium burnable absorber is used to decrease the relative power of fresh fuel assemblies. In this paper, the effect of the axial distribution of gadolinium (Gd) on the power of the APWR assembly is studied. Three models of APWR assemblies are simulated using MCNP6 code. In the first model, $\mathrm{UO}_{2}$ fuel is distributed uniformly in all the fuel rods. In the other two models some of the $\mathrm{UO}_{2}$ fuel rods are replaced by $\mathrm{UO}_{2}-\mathrm{Gd}_{2} \mathrm{O}_{3}$ rods in part length distribution. Two gadolinium concentrations $6 \%$ and $10 \%$ are used. The main neutronic parameters are estimated for the three models: the multiplication factor (K-infinity) as a function of burnup (GWd/MTU), the radial and axial power distributions. The results show that the distribution of the gadolinium absorber in the central region of fuel rod (part-length absorber) leads to flattening of axial power, which means additional axial power distribution control.

Ke y w ords: Advanced Pressurized Water Reactor (APWR), burnable poisons, gadolinium (Gd), burnup, radial power distribution, axial power distribution.

(c) Hend M. Saad, Riham Refeat, Moustafa Aziz, H. Mansour, 2019

The Advanced Pressurized Water Reactor (APWR) has been developed as a joint international cooperative development project between the Japanese PWR electric power companies and Mitsubishi Heavy Industries and Westinghouse. APWR is a generation
III nuclear reactor design developed by Mitsubishi Heavy Industries (MHI) in Japan based on pressurized water reactor technology[1]. Generation III nuclear reactors are essentially generation II reactors with evolutionary design improvements in several 
areas, namely, fuel technology, thermal efficiency, modularized construction, safety systems, and standardized design for each type. These improvements are subject to expedite licensing, reduce the capital cost and construction time. Improvements in generation III reactor technology have aimed at a longer operational life, typically 60 years of operation. A simpler and more rugged design makes them easier to operate and less vulnerable to operational upsets. Further, it reduced possibility of core melt accidents. Stronger reinforcement against aircraft as compared to earlier designs helps to resist radiological release. Higher burnup of fuel increases efficiently and reduce the amount of waste produced. Greater use of burnable absorbers ('poisons') contributes fuel life extension [2]. The first APWR plants were approved by the Japan Atomic Power Company, namely Tsuruga-3 and 4 producing $1538 \mathrm{MWe}$. The basic design concepts of the US-APWR are similar to those of Japanese APWR designs. In particular, the US-APWR has been developed as a large-scale version for the advanced pressurized water reactor aiming at higher electrical outputs and improved economics [1]. US-APWR has a $4451 \mathrm{MWt}$, about $1600 \mathrm{MWe}$ net, due to longer ( $4.3 \mathrm{~m}$ instead of $3.7 \mathrm{~m}$ in earlier designed PWR) fuel assemblies, higher fuel rod average burnup (62 GWd/t) and higher thermal efficiency (37\%). It has 24-month refuelling cycle. The most important requirement of a nuclear power plant is to ensure safety. Therefore, US-APWR incorporates numerous technical improvements to enhance its safety features $[3,4$, and 5$]$.

\section{Reactor Description}

The US-APWR core consists of 257 fuel assemblies surrounded by a stainless-steel radial neutron reflector designed to improve neutron utilization, which reduces the fuel cycle cost and significantly reduces reactor vessel irradiation compared to previous PWRs with baffle/barrel designs [1].

The US-APWR fuel assembly utilizes a $17 \times 17$ array of 264 fuel rods, 24 control rod guide thimbles (GT) and one in-core instrumentation guide tube (IT) as presented in Fig. 1.

The fuel rod consists of ZIRLO ${ }^{\text {TM }}$ fuel cladding loaded with sintered uranium dioxide pellets and/ or sintered Gadolinia-uranium dioxide pellets, a coil spring in the upper plenum, a lower plenum spacer,

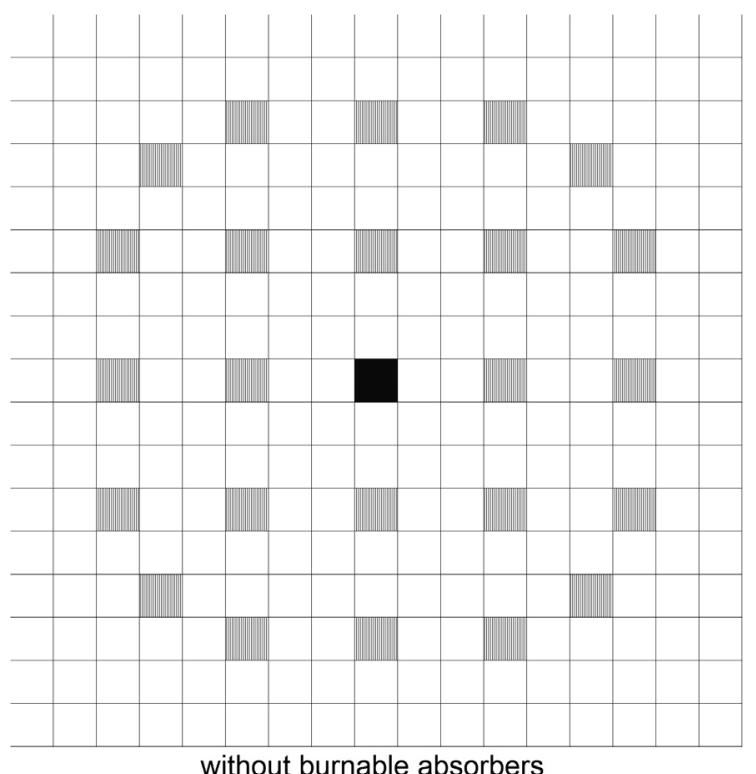

without burnable absorbers

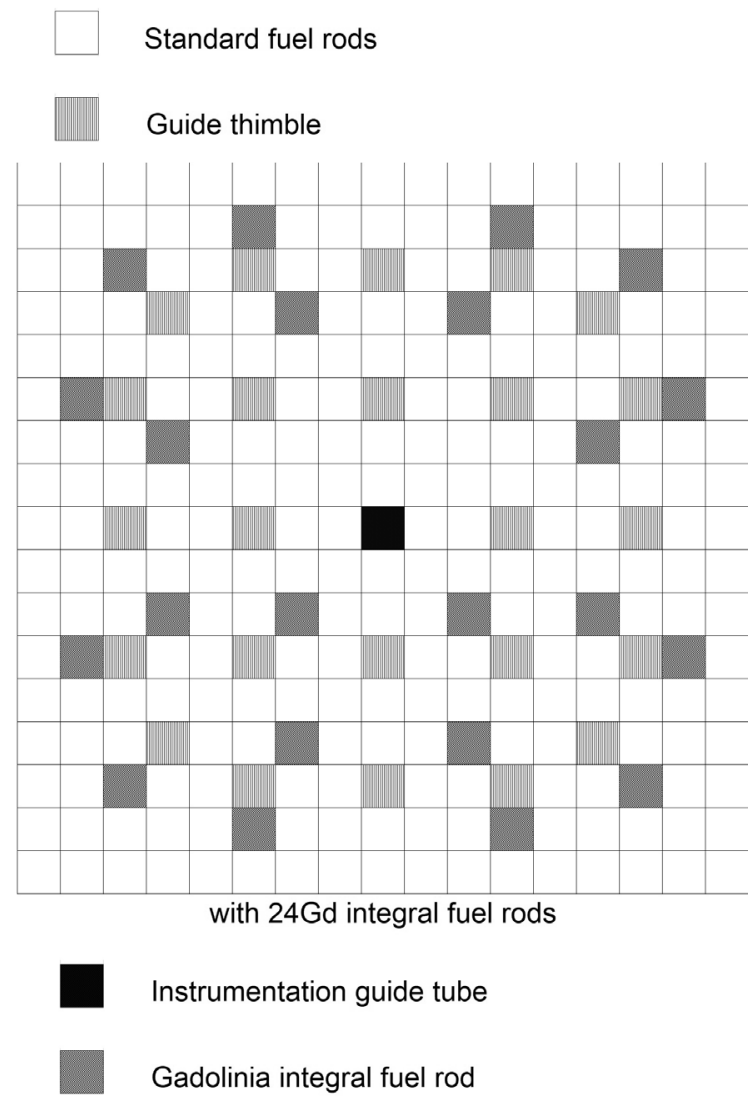

Fig. 1 - Arrangement of fuel and burnable poison rods within fuel assembly

and end plugs welded at the top and bottom ends to seal the rod. To reduce pellet/cladding interaction and prevent collapse during normal operation, the fuel rods are pressurized with helium through a pressurization hole provided in the top end plug, 


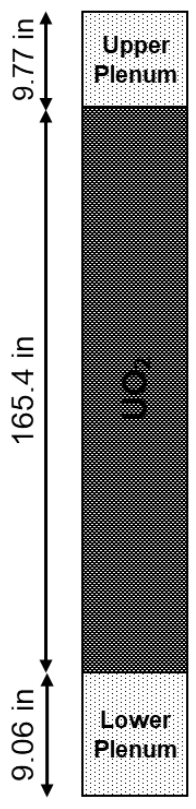

Model A

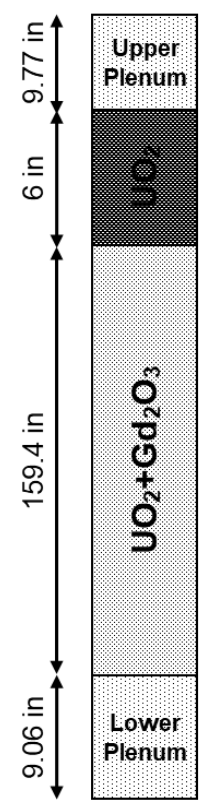

Model B

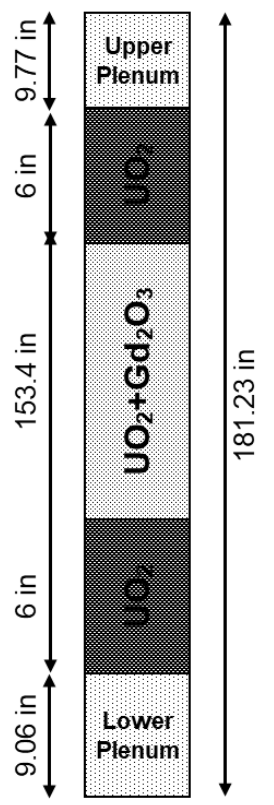

Model C
Fig. 2 - Schematic view of fuel rod

which is then closed off by welding to yield a sealed structure. The US-APWR fuel rod with upper and lower plenums has enough free volume to accommodate the fission gas release. In Fig. 2, a simplified presentation is provided for the APWR fuel rods.

Some fuel rods may have fuel pellets containing gadolinia $\left(\mathrm{Gd}_{2} \mathrm{O}_{3}\right)$ integral burnable absorber in part-length axial configurations to control excess reactivity and power distribution. In all modern nuclear reactors, burnable poisons are used to permit higher loading of fuel without the necessity of an overly large control rod system, which in turn permits a longer core life and can limit the level of power distribution. Gadolinium burnable poison has some very strongly absorbing isotopes, but not all have large cross-sections and result in residual burnable poison reactivity worth at the end of the fuel life. Burnable absorbers work by neutron capture on a large cross-section isotope (eg. Gd-155 and Gd-157 [6]). Gadolinium burnable poisons have the unfavourable effect of decreasing the thermal conductivity of $\mathrm{UO}_{2}-\mathrm{Gd}_{2} \mathrm{O}_{3}$ fuel leading to higher temperature profiles in the fuel. In order to avoid such hot spots, the currently available APWR rods use lower U-235 enrichment in all fuel pellets containing gadolinium.

Detailed description of the US-APWR fuel rod and fuel assembly design features are presented in reference [1].
The objective of the presented paper is to investigate the neutronic behaviour of APWR fuel that use $\mathrm{UO}_{2}-\mathrm{Gd}_{2} \mathrm{O}_{3}$ with $6 \%$ and $10 \%$ concentrations in which the gadolinium content is partially distributed along the fuel rod. Three models have been simulated. The first model used enriched uranium $(4.15 \%)$ distributed uniformly in all the fuel rods of the assembly, while the other two models used enriched $\mathrm{Gd}$ with different gadolinia $\left(\mathrm{Gd}_{2} \mathrm{O}_{3}\right)$ concentrations and axial distribution. MCNP6 code is used to evaluate the effect of the gadolinium distribution in the fuel rod on normalized radial and axial power of fuel assembly. Calculations are performed to obtain the variation of $k_{\infty}$ with Burnup, pin power peaking factors, and the depletion of gadolinium isotopes (Gd-155, Gd-157). All the results are presented graphically and discussed.

\section{APWR Computer Model}

MCNP6 code $[7,8]$ is used to simulate three models for the APWR assemblies that differ according to the type of fuel rod configurations as described in Fig. 2. The first one consists of only $\mathrm{UO}_{2}$ fuel pellets model $(A)$, the second fuel rod consists of two parts with $\mathrm{UO}_{2}$, and $\mathrm{UO}_{2}-\mathrm{Gd}_{2} \mathrm{O}_{3}$ fuel pellets model (B), and the third consists of three parts with $\mathrm{UO}_{2}-\mathrm{Gd}_{2} \mathrm{O}_{3}$ in the central part and $\mathrm{UO}_{2}$ fuel pellets on the peripherals model (C). MCNP6 code is used to calculate the infinite multiplication factors, the radial and axial power distributions for the three models $(A, B$, and $C$ ) using cross-section data library (ENDF/B-VII.1) [9].

The particle radiation transport code MCNP, which stands for Monte Carlo N Particle, is a general-purpose, continuous-energy, generalizedgeometry, time-dependent, Monte Carlo radiationtransport code designed to track many particle types over broad ranges of energies. MCNP6 ${ }^{\mathrm{TM}}$ [10] represents the culmination of a multi-year effort to merge the MCNP5 ${ }^{\mathrm{TM}}$ and MCNPX' ${ }^{\mathrm{TM}}$ codes into a single product comprising all features of both. The new features include treatment of large amount of particles, inclusion of model physics options for energies above the cross-section table range, burnup feature and delayed particle production. The MCNP6 code represents one of a set of synergistic capabilities developed at Los Alamos that also includes the evaluated nuclear data files 


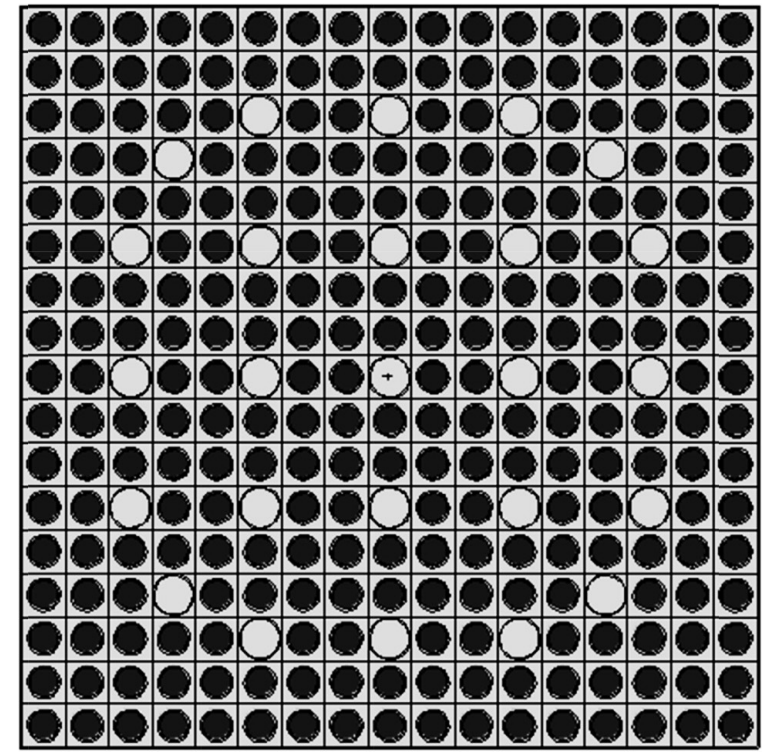

Fig. $3-$ MCNP6 cross-sectional view $f$ or model (A) without burnable absorbers

(ENDF/B-VII) and the data processing code NJOY $[9,10,11,12]$.

MCNP6 cross-sectional view of the $17 \times 17$ fuel assembly is presented in Fig. 3 and 4.

\section{Calculation Results and Discussion}

The maximum infinite multiplication factor is calculated for model (A) and compared with reference 1 . The initial conditions are used: fresh uranium fuel concentration of $4.15 \%$, temperature of cold shutdown (68F), No xenon (NoXe), no soluble boron (zero ppm) for beginning of cycle (BOC). Using MCNP6 codeand library ENDF/B-VII.1 [9], the maximum fuel assembly $k_{\infty}$ of the present work is presented in table 1 . It is noticed that the difference between the present model and the reference is $61 \mathrm{pcm}$ with estimated relative error equal to 0.00039 . The result shows a great accurate value and a good agreement. This indicated that the current version of MCNP6 and the nuclear data library used (ENDF/B-VII) can accurately simulate the APWR.

Table 1 - The Maximum fuel assembly k $\infty$ for Model (A)

\begin{tabular}{|c|c|c|}
\hline APWR Assembly & Present Model & Reference \\
\hline Multiplication Factor & 1.45539 & 1.456 \\
\hline
\end{tabular}

In the next sections, the burnup calculations are determined for the three models $(A, B$, and $C)$ with $\mathrm{Gd}-$ content $(6,10) \%$ in models $B$ and $C$. Then the radial and axial power distributions are determined and analysed.

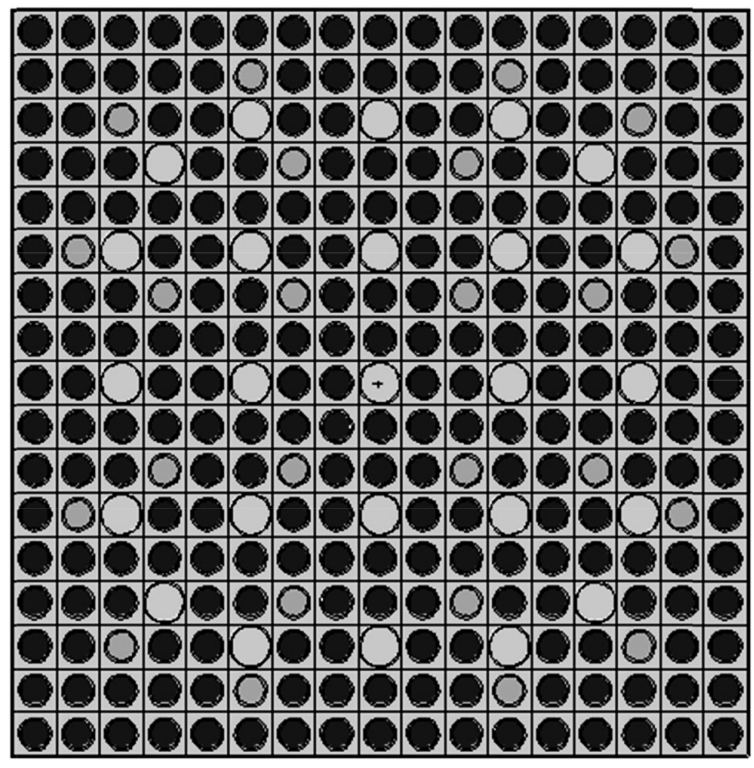

Fig. 4 - MCNP6 cross-sectional view for models $(B \& C)$ with $24 \mathrm{Gd}$ integral fuel rods

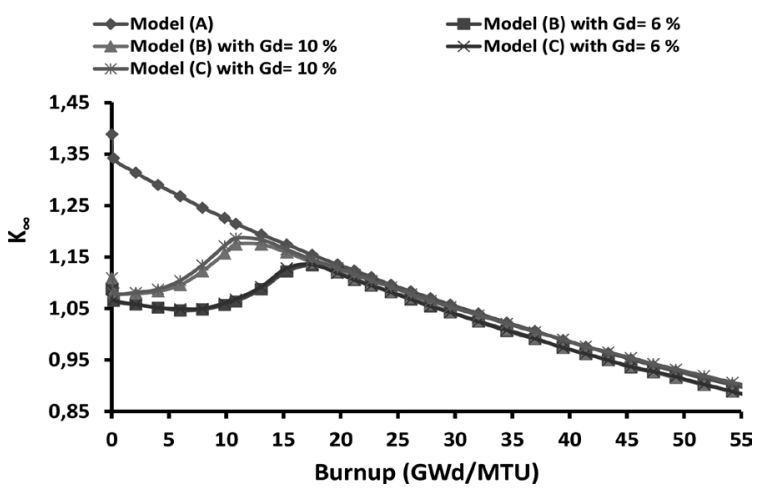

Fig. 5 - Comparison of $\mathrm{k}_{\infty}$ between model (A) and models $(B, C)$ with $\mathrm{Gd}$-content $=6$ and $10 \%$

\section{Burnup Calculation}

The APWR fuel assembly is burned up to the assembly average burnup (55 GWd/MTU). The values of the $\mathrm{k}_{\infty}$ obtained for the three models are presented in Fig. 5. Comparing the results obtained from the two models $(B, C)$ of $\mathrm{Gd}$-content $(6,10) \%$ and those of model $(A)$ showed the effect of adding gadolinium as a burnable poison in decreasing the value of $(\mathrm{k}-\infty)$ at $(0 \mathrm{GWd} / \mathrm{MTU})$. The values of $\mathrm{k}_{\infty}$ obtained for models ( $B$ and $C$ ) increased reaching a maximum value at a burnup (11 GWd/MTU) and then decreased with burnup until it reached its minimum value at ( $55 \mathrm{GWd} / \mathrm{MTU}$ ). It is clear that using model (C) with gadolinium concentration $10 \%$ gives better value for $k-\infty$, which 
Table 2 - The values of $\mathrm{K}-\infty$ for models $(\mathrm{A}, \mathrm{B}$, and $\mathrm{C}$ )

\begin{tabular}{|c|c|c|c|c|c|}
\hline $\begin{array}{c}\text { Burnup } \\
\text { (GWd/MTU) }\end{array}$ & Model (A) & $\begin{array}{c}\text { Model (B) } \\
\text { with Gd=6\% }\end{array}$ & $\begin{array}{c}\text { Model (B) } \\
\text { with Gd= 10 \% }\end{array}$ & $\begin{array}{c}\text { Model (C) } \\
\text { with Gd=6\% }\end{array}$ & $\begin{array}{c}\text { Model (C) } \\
\text { with Gd= 10 \% }\end{array}$ \\
\hline 0.0 & 1.38851 & 1.08744 & 1.10886 & 1.08782 & 1.10986 \\
\hline 0.15 & 1.34218 & 1.06501 & 1.08144 & 1.06667 & 1.08012 \\
\hline 2.00 & 1.31390 & 1.05774 & 1.07920 & 1.05811 & 1.08119 \\
\hline 4.00 & 1.29015 & 1.05175 & 1.08341 & 1.05173 & 1.08749 \\
\hline 6.00 & 1.26812 & 1.04647 & 1.09566 & 1.04932 & 1.10432 \\
\hline 8.00 & 1.24567 & 1.04828 & 1.12233 & 1.04995 & 1.13451 \\
\hline 10.00 & 1.22613 & 1.05713 & 1.15667 & 1.06031 & 1.17199 \\
\hline 15.00 & 1.17459 & 1.12209 & 1.15902 & 1.12857 & 1.16468 \\
\hline 20.00 & 1.13574 & 1.12039 & 1.12234 & 1.11887 & 1.12897 \\
\hline 30.00 & 1.05776 & 1.04266 & 1.04339 & 1.04262 & 1.05328 \\
\hline 40.00 & 0.98879 & 0.97469 & 0.97380 & 0.97392 & 0.99023 \\
\hline 50.00 & 0.92844 & 0.91605 & 0.91536 & 0.91745 & 0.93208 \\
\hline 55.00 & 0.90199 & 0.88917 & 0.88898 & 0.88886 & 0.90652 \\
\hline
\end{tabular}

means higher burnup is achieved than in case of using models (A) and (B). Table 2 presents the values of the $\mathrm{K}-\infty$ at the different burnup values obtained for the models $(B, C)$ with different $\mathrm{Gd}$ - content $(6,10) \%$ and compared with model (A).

\section{Radial Power Distribution}

Pin-by-pin power distribution for the three models of fuel assemblies is presented in Fig. 6, 7 for half assembly. The values provided are normalized radial power distribution at zero state, no xenon (NoXe), and zero (ppm) conditions for beginning of cycle (BOC).

Fig. 6 shows the radial power distribution for the three models $(A, B$, and $C)$ with gadolinium concentration $6 \%$ for models ( $B$ and $C$ ). The upper value belongs to model $(A)$ assembly with no burnable poison rods. It is shown that the power tends to be lower at the edges and increases towards the interior, this is due to the presence of the moderating medium at the guide tubes and the neutron leakage at the edges where there is a water gap surrounding each of the fuel assemblies.

In this case, the fuel rod with maximum power is located near the edge of assembly, the value of max. power $=1.063$.

The middle value belongs to model (B) assembly with (24) burnable poison rods. It is shown that the radial normalized power tends to have the maximum power rod at the center, the value of max. power $=1.173$.

The last value belongs to model (C) assembly with (24) burnable poison rods. It is indicated that the radial normalized power tends to have the max. power rod at the center, the value of max. power $=1.170$.

Fig. 7 presents the radial power distribution for the three models $(A, B$, and $C)$ with gadolinium concentration $10 \%$ for models ( $B$ and $C$ ). The upper value belongs to model $(A)$ assembly with maximum power value of 1.063 . The middle value belongs to model (B) assembly; it is shown that the radial normalized power tends to have the maximum power rod at the center, the value of max. Power equals to 1.173. The last value belongs to model (C) assembly, it is indicated that the radial normalized power tends to have the maximum power rod at the center, the value of max. power is 1.167.

\section{Axial Power Distribution}

The effect of axial distribution of gadolinium in fuel rod at BOC is expressed by the axial power distribution in the fuel assembly models (A, B, and $C$ ). To calculate the axial power distribution, the assembly is divided into 28 axial zones and the normalized average power in each zone is calculated. 
Fig. 6-The radial power distribution for model (A) and models (B) and (C) with Gd-Content $=6 \%$
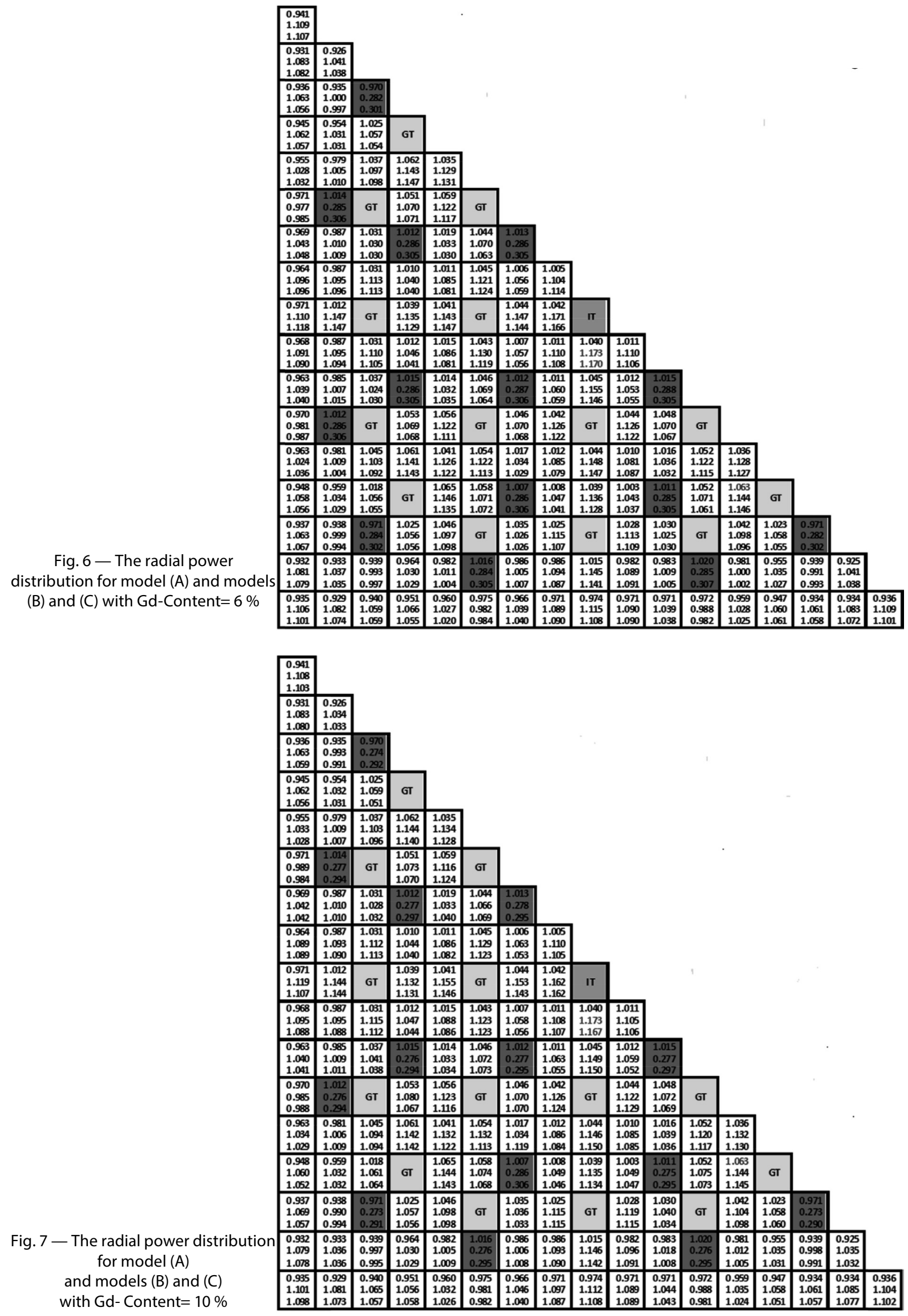


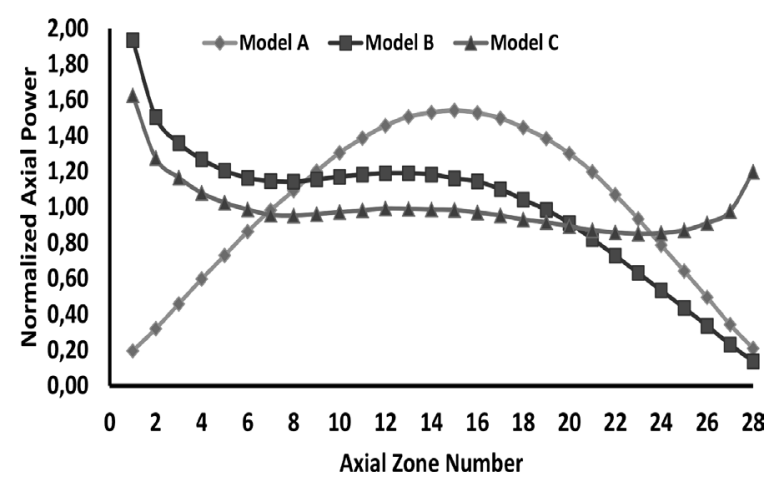

Fig. 8 - The axial power distribution comparison between model ( $A$ ) and models $(\mathrm{B}, \mathrm{C})$ with $\mathrm{Gd}$-Content $6 \%$

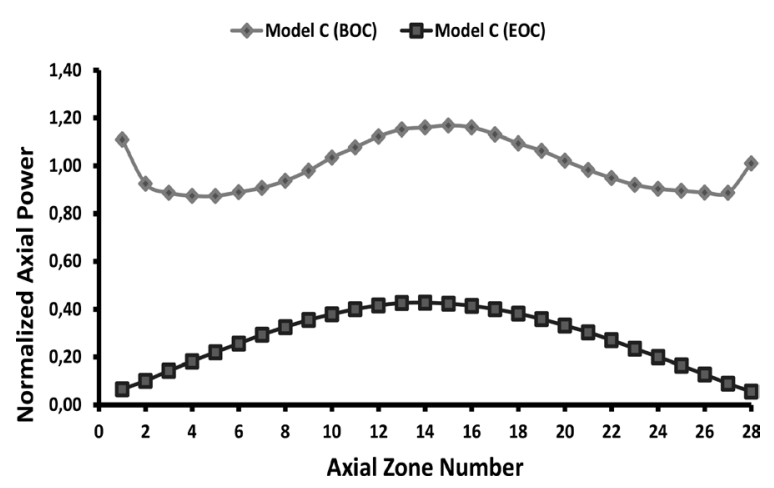

Fig. 10 - The axial power distribution for model (C) with Gd-Content $10 \%$ at (BOC)and (EOC)

Fig. 8, 9 show normalized axial power distribution for the three models (A, B, and C) typical initial assemblies, with gadolinium concentrations $6 \%$ and $10 \%$ for models (B) and (C). The max. power for model (A) assembly is 1.54 due to the absence of gadolinium. It is noticed that the power peak of normalized axial power distributions is decreased in case of adding gadolinium rods models ( $\mathrm{B}$ and $\mathrm{C}$ ) with $6 \%$ and $10 \%$ contents. It is noticed that, the maximum power for model (B) at $6 \%$ concentration is equal to 1.93 and at $10 \%$ concentration is equal to 1.38 . It is also shown that a corresponding flattening of the power profile is observed in the central region of the assembly for model (C). Moreover, model (C) with $10 \%$ gadolinium content is more flattened than $6 \%$ because of the quantity of gadolinium distributed in fuel rod is larger, which leads to additional axial power distribution control.

Fig. 10 illustrates the effect of gadolinium in fuel rod on the axial power of model (C) (Gdcontent $=10 \%)$ at BOC and EOC. It is observed

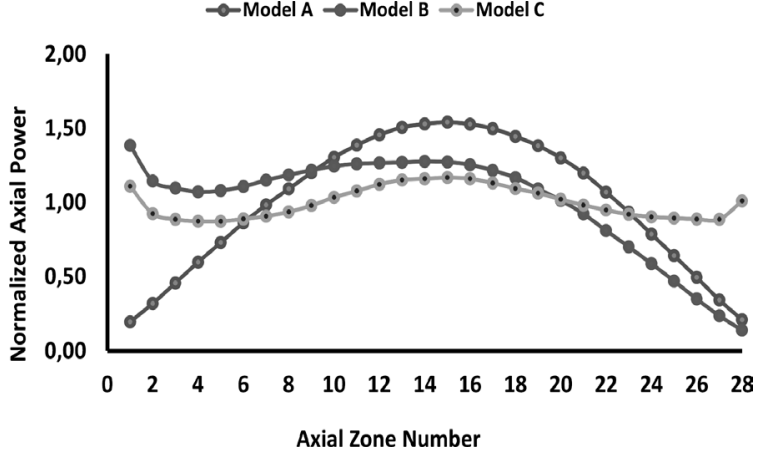

Fig. 9-The axial power distribution comparison between model (A) and models $(B, C)$ with Gd-Content $10 \%$

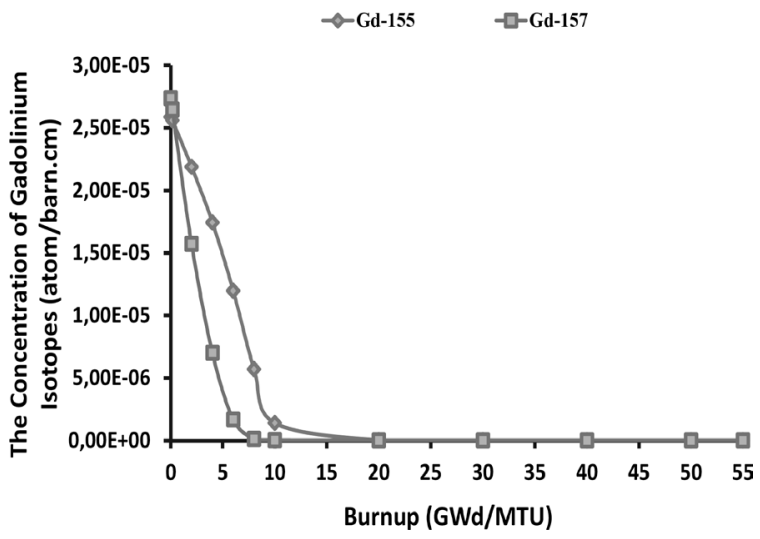

Fig. 11 - Gadolinium isotopes concentrations versus burnup (GWd/MTU) for model (C) with Gd-Content $10 \%$

that the effect of gadolinium is diminished at EOC due to the depletion of gadolinium throughout the burnup process. At the EOC, gadolinium is completely depleted and has no effect on the power. The depletion of gadolinium isotopes Gd-155 and Gd-157 with burnup till ( 55 GWd/MTU) is presented in Figure 11. There is a sharp decrease in the Gd-157 concentration because of its high neutron absorption cross-section. It is fully burned at 10 (GWd/MTU). The concentration of Gd-155 decreased smoothly with increasing the full power days and fully burned out at 20 (GWd/MTU).

\section{Conclusion}

In the present work, the effect of the axial distribution of gadolinium (Gd) in the fuel rod onto the assembly power is studied. Three models of APWR assemblies are simulated using MCNP6 code. In the first assembly, $\mathrm{UO}_{2}$ fuel is distributed 
uniformly in all the fuel rods. In the other two assemblies some of the $\mathrm{UO}_{2}$ rods are replaced by $\mathrm{UO}_{2}-\mathrm{Gd}_{2} \mathrm{O}_{3}$ in part length distribution. Two gadolinium concentrations are used $6 \%$ and $10 \%$. For each of the three models, the main neutronic parameters are estimated: the multiplication factor (K-infinity) as a function of burnup (GWd/MTU), the radial and axial power distributions. Comparison of the results obtained during Burnup for models $(B, C)$ with Gd-content $(6,10) \%$ and those of model $(A)$ showed the effect of adding gadolinium as a burnable poison. It is concluded that using model (C) with $10 \%$ gadolinium can extend burnup levels to higher values than those obtained for models (A and B). The value of k-infinity for model (C) is 0.90652 higher than that of the other models. The results for radial and axial power distributions showed that the distribution of the gadolinium absorber in the central region of fuel rod to obtain a part-length absorber leads to flattening in axial power distribution and additional power control. Moreover, the model with $10 \%$ gadolinium content is more flattened than that with $6 \%$ gadolinium, because of the quantity of gadolinium distributed in fuel rod is larger, which leads to additional axial power distribution control.

\section{References}

1. Design control document for the US-APWR, Chapter 4 Reactor, MUAP- DC004, Rev. 4, August 2013.

2. The document retrieved from http://www.worldnuclear.org/information-library/nuclear-fuelcycle/ nuclear-power-reactors/advanced-nuclear-power-reactors.aspx.

3. Mitsubishi fuel design criteria and methodology. MUAP07008-P-A Rev. 2, (Proprietary) and MUAP-07008-NP-A Rev.2 (Non-Proprietary), July 2013.

4. US-APWR fuel system design evaluation. MUAP-07016-P Rev. 4 (Proprietary) and MUAP-07016-NP Rev. 4 (Non-Proprietary), August 2013.

5. US-APWR fuel system design parameters list. MUAP-07018-P Rev. 0 (Proprietary) and MUAP-07018-NP Rev.0 (Non-Proprietary), December 2007.

6. IAEA-TECDOC-844. Characteristics and use of uraniagadolinia fuels. International Atomic Energy Agency, 1995.

7. Pelowitz, D. B., (2013). MCNP6 TM user's manual. Ver. 1.0, Manual Rev. 0, Los Alamos National Laboratory Report, LA-CP-13-00634, Rev. 0.

8. Goorley, T., et al. (2012). Initial MCNP6 release overview. Nuclear Technology, 180, pp. 298-315.

9. Chadwick, M.B., et.al. (2011). ENDF/B-VII.1: Nuclear data for science and technology: cross-sections, covariances, fission product yields and decay data. Nuclear Data Sheets, 112.

10. Goorley, T. (2014). MCNP6.1.1 beta release notes. LA-UR-14-24680.
11. MCNP5: X-5 Monte Carlo Team, MCNP - Ver. 5, Vol. I: Overview and Theory. LA-UR-03-1987, 2003.

12. Pelowitz, D.B. (2011). MCNPX User's Manual. Ver. 2.7.0, LA-CP-11-00438.

\section{Вплив осьового розподілу гадолінієвого вигоряючого поглинача в удосконалених ядерних реакторах з водою під тиском}

\section{Хенд М. Саад ${ }^{1}$, Ріхам Рефеут ${ }^{1}$, Мустафа Азіз ${ }^{1}$, Х. Мансур ${ }^{2}$}

1 Відділ технічного забезпечення ядерної безпеки, Орган регулювання ядерної та радіологічної безпеки, Наср-Сіті, Каїр, Єгипет

2 Кафедра фізики, факультет природничих наук, Каїрський університет, Гіза, Єгипет

Радіальне та осьове розподілення потужності в енергетичних реакторах головним чином визначаютьсязадопомогоюструктуритепловиділяючих збірок та вигоряючого поглинача на початку циклу. В удосконалених ядерних реакторах з водою під тиском (APWR) гадолінієвий вигоряючий поглинач використовується для зниження відносної потужності свіжих тепловиділяючих збірок. У цій роботі розглядається вплив осьового розподілення гадолінію (Gd) на потужність APWR. За допомогою коду MCNP6 було змодельовано три моделі збірок APWR. У першій моделі паливо $\mathrm{UO}_{2}$ рівномірно розподіляється в усіх тепловиділяючих елементах (твел). У двох інших моделях деякі з твелів з $\mathrm{UO}_{2}$ замінюються твелами $3 \mathrm{UO}_{2}-\mathrm{Gd}_{2} \mathrm{O}_{3}$. Використовується дві концентрації гадолінію в $6 \%$ і $10 \%$. Була проведена оцінка двох основних нейтронно-фізичних параметрів для трьох моделей: коефіцієнт розмноження (К-нескінченність) як функція вигоряння (GWd/ MTU), радіальний і осьовий розподіл потужності. Результати показують, що розподіл вигоряючого поглинача в центральній області твела (укорочені поглиначі) викликає вирівнювання осьового розподілу потужності, що призводить до необхідності додаткового контролю осьового розподілу потужності.

К люч ов і сл ов а: вдосконалений ядерний реактор з водою під тиском (APWR), вигоряючий поглинач, гадоліній (Gd), вигоряння, радіальний розподіл потужності, осьовий розподіл потужності.

Отримано 16.04.2019 